\title{
Analysis of Nifty Movement on Share Prices of Selected Construction Companies
}

\author{
M. Gomathi ${ }^{1}$, Dr.S.Nirmala ${ }^{2}$ \\ ${ }^{1}$ M.Phil Research Scholar, ${ }^{2}$ Associate professor \\ Department of Business Management, PSGR Krishnammal College for Women, Coimbatore
}

\begin{abstract}
This study aims at analyzing and predicting the price movements of construction companies stocks contributing to the NIFTY50 Index. To analyze the volatility of telecom stock and understand the behavior of stock prices in construction sector stocks i.e. (JP ASSOCIATES LIMITED, DLF LIMITED, GAMMON INDIA LIMITED, PUNJ LLOYD LIMITED, HCC LIMITED).

The data for these stocks are collected from magazines, newspaper and websites. The stocks are analyzed by monitoring their respective price movements using technical tools. The technical tools used in this study are Exponential moving average, Relative strength index, Rate of change, MACD. Using these tools the trend over the recent past was deciphered. The expected trend in the immediate future was also predicted.

Technical Analysis studies the price and volume movement in the market and predicts the future. It helps in identifying that the best time to buy and sell equity. Technical Analysis is a method of evaluating equities by analyzing the statistics generated by market activity, such as past prices and volume.
\end{abstract}

Keyword: Technical analysis, Rate of Change, Relative strength index.

\section{INTRODUCTION}

Technical analysis studies share's price movement, volume traded over years and they try to Predict future price movements of shares. Technical analysis do not attempt to measure a security's intrinsic value, but instead use charts and other tools to identify patterns that can suggest future activity. Technical analysis entirely based on prices and do not include balance sheets, P\&L accounts (fundamental analysis). technical analysis is more dynamic as compared to fundamental analysis because it depend on corporate events like earnings of firm, policy changes.

Technical analysis of selected companies share helps to know about the price behavior of the share, the signals (buy or sell), demand and supply of company share in market. The investor can use technical analysis as tool to decide on investment in stock or to sell stock at that point of time.

\section{AN OVERVIEW OF CONSTRUCTION INDUSTRY}

India is the second fastest growing economy in the world. The Indian construction industry is an integral part of the economy and a conduit for a substantial part of its development investment, is poised for growth on account of industrialization, urbanization, economic development and people's rising expectations for improved quality of living. Construction accounts for nearly 65 per cent of the total investment in infrastructure and is expected to be the biggest beneficiary of the surge in infrastructure investment over the next five years. Investment in construction accounts for nearly 11 per cent of India's Gross Domestic Product (GDP). $€ 239.68$ billion is likely to be invested in the infrastructure sector over the next five to 10 years which would provide a huge boost to the construction industry as a whole.

\section{REVIEW OF LITERATURE}

1. S.Vijai "predictive ability of fundamental and technical analysis", examined the stock market index movement for the period of $2000-2005$ and conclude that the stock 
market index movement has a close correlation with 2 major fundamental parameters, namely GDP and FII inflow. Author make a suggestion that model used for predicting the movement in sensex using technical analysis better compare to fundamental analysis. For the research process he takes a period of 2000-2005.

2. Narendra, N.Patel "trading through technical analysis", explained RSI is more useful in stock price analysis when comparing with MACD as it has more accuracy and generate more signals then MACD and provide more clear guidelines for entry and exit from the market

3. Ravindra and Wang (2006) examine the relationship of trading volume to stock indices from six developing markets. Study made over 34 month period and ended on October 2005. In the South Korean market, the causality extends from the stock indices to trading volume while the causality is the opposite in the Taiwanese market.

4. Gupta, (2003) examined the perceptions about the main sources of his worries concerning the stock market. A sample comprise of middle-class household's spread over 21 sates/union territories. The study reveals that the foremost cause of worry for household investors is fraudulent company management and in the second place is too much volatility and in the third place is too much price manipulation.

C.L.Osler (2001) studied the success of two familiar predictions from technical analysis: (1) trends tend to be reversed at predictable support and resistance levels, and (2) trends gain momentum once predictable support and resistance levels are crossed. The explanation is based on a close examination of stop-loss and take-profit orders at a large foreign exchange dealing bank. Take-profit orders tend to reflect price trends, and stop-loss orders tend to intensify trends. The requested execution rates of these orders are strongly clustered at round numbers, which are often used as support and resistance levels. Significantly, there are marked differences between the clustering patterns of stop-loss and take-profit orders, and between the patterns of stop-loss buy and stop-loss sell orders. These differences explain the success of the two predictions.

\section{OBJECTIVES OF THE STUDY}

The following the objectives of the study,

1. To understand the stock market behavior by studying the price movement of the selected companies share prices from a construction industry.

2. To know the selected companies stock price pattern in particular trend or trend reversal.

3. To offer better ways and means to the investors for their investment decision.

\section{RESEARCH METHODOLOGY}

Research is a systematic and continues method of defining a problem, collecting the facts and analyzing them, reaching conclusion forming generalizations. Research methodology is a way to systematically solve the problem. It may be understood has a science of studying how research is done scientifically.

\subsection{Research Design}

A research design is the arrangement of condition for collection and analysis of data in a manner that aims to combine relevance to the research purpose with economy in procedure. It is the conceptual structure within which research is conducted. Analytical Research is used in this study.

\subsection{Sources of Data}

The main sources of data for the present study used are secondary in nature. Secondary data consists of information that already exists somewhere and has been collected for specific purpose in the study. The source of secondary data is collected from Company records, Newspaper, Company websites, NSE. Share price and nifty index for selected companies are collected from www.nseindia.com.

\subsection{Period of study}

Study is conducted for the period of (145 days) $1 / 07 / 2011$ to $31 / 01 / 2012$.

\subsection{Tools Used For Analysis}

Statistical tools are used to analyses Indian stock market using past data and information. 


\subsection{Rate of Change Indicator (ROC)}

It is a very popular oscillator which measures the rate of change of the current price a compared to the price a certain number of days or weeks back. To calculate a 7 day rate of change, each day's price is divided by the price which prevailed 7 days ago and then 1 is subtracted from this price ratio.

ROC $=$ Current price/Price ' $n$ ' period ago -1

The ROC values may be positive, negative or Zero. When the ROC line is above the zero line, the price is rising and when it is below the zero line, the price is falling. If the scrip's ROC reaches the historic high values, the scrip is in the overbought region and a fall in the value can be anticipated. Likewise, if the scrip's ROC reaches the historic low value, the scrip is in the oversold region, rise in the scrip's price can be anticipated.

\subsection{Relative strength index (RSI)}

Relative Strength Index (RSI) is a momentum oscillator that measures the speed and change of price movements. RSI oscillates between zero and 100. When RSI of share is lies between 30 and 70 investors can hold share and if it RSI crosses 70 there may be downturn and it is time to sell.

$$
\begin{gathered}
100 \\
\text { RSI }=100----- \\
1+\text { RS }
\end{gathered}
$$

RS = Average Gain / Average Loss

Average Gain $=[($ previous Average Gain $) \times 13+$ current Gain] / 14.

Average Loss $=[$ (previous Average Loss $) \times 13+$ current Loss] / 14.

\section{Correlation}

Correlation is a tool to identify the relationship level between selected variable. Correlation analysis helps in determining the degree to which the variables are related to each other. Correlation may be positive or negative. When the two variables are moves in the same direction it is called as positive correlation. When the two variables are moves in the opposite direction it is called as negative correlation.

\section{DATA ANALYSIS INTERPRETATION}

AND

\section{RATE OF CHANGE (ROC) JP ASSOCIATES LIMITED}

Chart of JP associate rate of Change (ROC) analysis shows that investor can sell the share in overbought area on $8^{\text {th }}$ September. The investor can buy the share in oversold area on $21^{\text {st }}$ November.

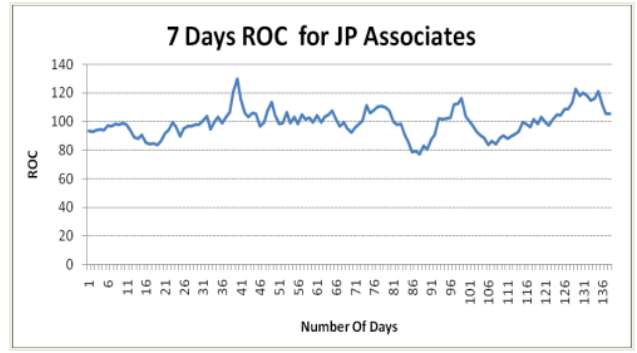

\section{DLF LIMITED}

Chart of DLF LIMITED Rate of Change (ROC) analysis shows that on $13^{\text {th }}$ October investor can sell share as Share price movements in overbought region. The investor can buy the shares on $17^{\text {th }}$ November as script fall under oversold region.

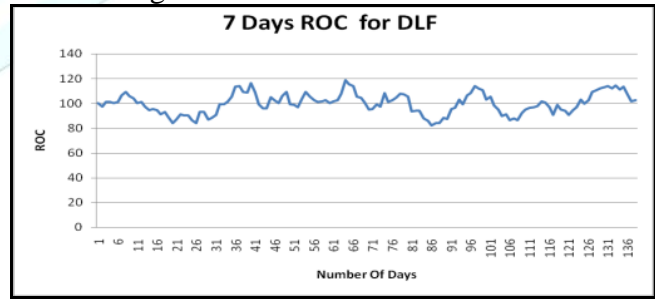

\section{GAMMON INDIA LIMITED}

Rate of Change (ROC) analysis chart of GAMMON INDIA shows the share price of scrip move in overbought region on $27^{\text {th }}$ January 2012 and in oversold region on $21^{\text {st }}$ November 2011. The investor can sell the share when script is in overbought region and buy the shares when it is in oversold region.

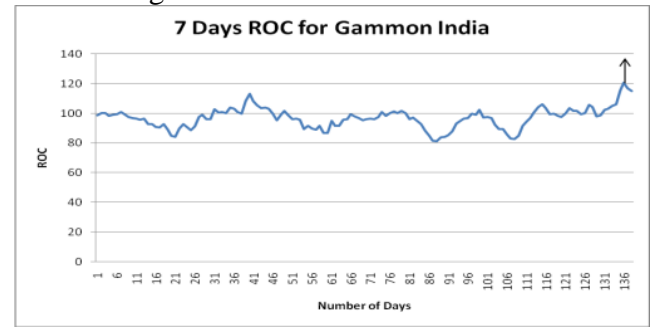




\section{PUNJ LLOYD LIMITED}

Chart Rate of Change (ROC) analysis of PUNJ LLOYD LIMITED shows that investor can sell the share in overbought area on $8^{\text {th }}$ September 2011. The investor can buy the share in oversold area on $21^{\text {st }}$ November 2011.

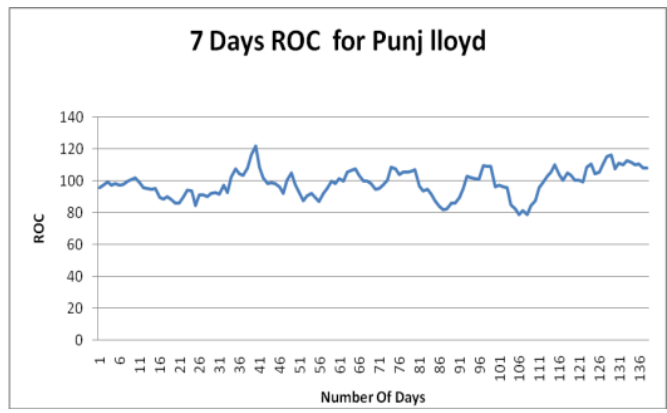

\section{HCC LIMITED}

Chart of Rate of Change (ROC) analysis for HCC LIMITED shows that Share price movements reach's overbought on $17^{\text {th }}$ January 2012 , where investor can sell share. The investor can buy the shares on $21^{\text {st }}$ November 2011 as script fall under oversold region.

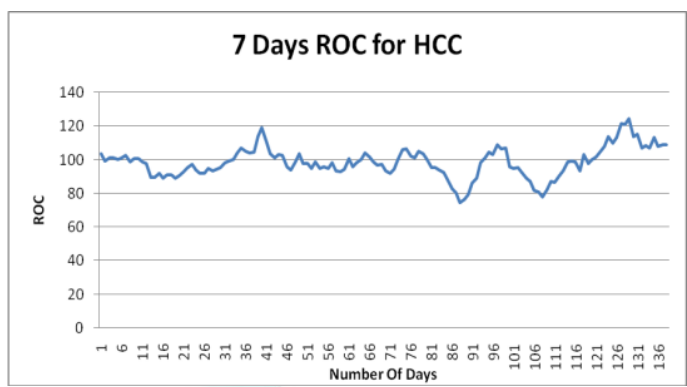

\begin{tabular}{|c|c|c|c|c|c|c|}
\cline { 2 - 7 } \multicolumn{1}{c|}{} & \multicolumn{2}{c|}{ ROC FOR JP ASSOCIATES } & \multicolumn{2}{c|}{ ROC FOR DLF } & \multicolumn{2}{c|}{ ROC FOR GAMMON INDIA } \\
\cline { 2 - 7 } \multicolumn{1}{c|}{} & Over bought & Over sold & Over bought & Over sold & Over bought & Over sold \\
\hline $\begin{array}{c}\text { Trading } \\
\text { day }\end{array}$ & 47 & 95 & 71 & 93 & 143 & 95 \\
\hline DATE & $08-09-11$ & $21-11-11$ & $13-10-11$ & $17-11-11$ & $27-01-12$ & $21-11-11$ \\
\hline $\begin{array}{c}\text { CLOSING } \\
\text { PRICE }\end{array}$ & 71 & 60.75 & 238.5 & 203.5 & 53.85 & 52.2 \\
\hline ROC & 129.7 & 77.38854 & 118.804 & 82.18901 & 120.7399 & 81.37178 \\
\hline
\end{tabular}

Table shows result of ROC (over bought and oversold) for selected companies.

\section{RELATIVE STRENGTH INDEXES (RSI) Table No - 2}

\begin{tabular}{|c|c|c|c|c|c|}
\hline TITLE & JP Associates Limited & DLF Limited & $\begin{array}{c}\text { Gammon India } \\
\text { Limited }\end{array}$ & $\begin{array}{c}\text { Punj Lloyd } \\
\text { Limited }\end{array}$ & $\begin{array}{c}\text { HCC } \\
\text { Limited }\end{array}$ \\
\hline Total gain & 127.2 & 396 & 65.15 & 83.6 & 40.75 \\
\hline Total loss & 138.7 & 400.25 & 107.35 & 107.55 & 49.55 \\
\hline $\begin{array}{c}\text { Average } \\
\text { gain }\end{array}$ & 1.74 & 5.5 & 1.123 & 1.194 & 0.62 \\
\hline $\begin{array}{c}\text { Average } \\
\text { loss }\end{array}$ & 1.95 & 5.56 & 1.34 & 1.45 & 0.66 \\
\hline $\begin{array}{c}\text { Relative } \\
\text { strength } \\
\text { (RS) }\end{array}$ & 0.89 & 0.99 & 0.83 & 0.82 & 0.93 \\
\hline $\begin{array}{c}\text { Relative } \\
\text { Strength } \\
\text { Index } \\
\text { (RSI) }\end{array}$ & 47.14 & 49.73 & 45.56 & 45.11 & 48.35 \\
\hline
\end{tabular}




\section{JP ASSOCIATES LIMITED}

It is identified from the above table that the Relative Strength Index (RSI) of JP associates, indicates that the RSI (47.14) lies between 30 and 70. It is suggested to the investors that they can hold the shares for some period.

\section{DLF LIMITED}

It is identified from the above table that the Relative Strength Index (RSI) of DLF LTD, indicates that the RSI (49.73) lies between 30 and 70. It is suggested to the investors that they can hold the shares for some period.

\section{GAMMON INDIA LIMITED}

It is identified from the above table that the Relative Strength Index (RSI) of GAMMON INDIA, indicates that the RSI (45.56) lies between 30 and 70. It is suggested to the investors that they can hold the shares for some period.

\section{PUNJ LLOYD LIMITED}

It is identified from the above table that the Relative Strength Index (RSI) of PUNJ LLOYD, indicates that the RSI (45.11) lies between 30 and 70. It is suggested to the investors that they can hold the shares for some period.

\section{HCC LIMITED}

It is identified from the above table that the Relative Strength Index (RSI) of HCC, indicates that the RSI (48.35) lies between 30 and 70. It is suggested to the investors that they can hold the shares for some period.

\section{CORRELATION}

Correlation is a tool to identify the relationship level between selected variable. Here the researcher made an attempt to identify the relationship level between share prices of Selected Companies in Construction Industry and NIFTY movement. For this purpose of this study the researcher formulated hypothesis is;

Ho: There is no relationship between share price movement of Selected Companies In Construction Industry and the movement of NIFTY value.

H1: There is a close relationship between share price movement of Selected Companies In Construction Industry and the movement of NIFTY value.

\section{CORRELATION FOR JP ASSOCIATES LIMITED}

\begin{tabular}{|c|c|c|c|}
\hline 1 & & NIFTY & $\begin{array}{c}\text { JP } \\
\text { ASSO }\end{array}$ \\
\hline \multirow[t]{3}{*}{ NIFTY } & Pearson Correlation & 1 & $.540^{* * *}$ \\
\hline & Sig. (2-tailed) & & .000 \\
\hline & $\mathrm{N}$ & 145 & 145 \\
\hline \multirow{3}{*}{$\begin{array}{l}\text { JP } \\
\text { ASSO }\end{array}$} & Pearson Correlation & $.540^{* * *}$ & 1 \\
\hline & Sig. (2-tailed) & .000 & \\
\hline & $\mathrm{N}$ & 145 & 145 \\
\hline \multicolumn{4}{|c|}{$\begin{array}{l}\text { **. Correlation is significant at the } 0.01 \text { level } \\
\text { (2-tailed). }\end{array}$} \\
\hline
\end{tabular}

\section{CORRELATION FOR DLF LIMITED}

\begin{tabular}{|l|l|c|c|}
\hline & & NIFTY & DLF \\
\hline \multirow{3}{*}{ NIFTY } & Pearson Correlation & 1 & $.473^{* *}$ \\
\cline { 2 - 4 } & Sig. (2-tailed) & & .000 \\
\cline { 2 - 4 } & $\mathrm{N}$ & 145 & 145 \\
\hline \multirow{5}{*}{ DLF } & Pearson Correlation & $.473^{* *}$ & 1 \\
\cline { 2 - 4 } & Sig. (2-tailed) & .000 & \\
\cline { 2 - 4 } & N & 145 & 145 \\
\hline \multirow{3}{*}{$* *$. Correlation is significant at the 0.01 level } \\
\hline \multicolumn{3}{|c|}{ (2-tailed). } \\
\hline
\end{tabular}

\section{CORRELATION FOR GAMMON INDIA LIMITED}

\begin{tabular}{|c|c|c|c|}
\hline & & NIFTY & $\begin{array}{c}\text { GAMMON } \\
\text { INDIA }\end{array}$ \\
\hline \multirow[t]{3}{*}{ NIFTY } & $\begin{array}{l}\text { Pearson } \\
\text { Correlation }\end{array}$ & 1 & $.809^{* * *}$ \\
\hline & Sig. (2-tailed) & & .000 \\
\hline & $\mathrm{N}$ & 145 & 145 \\
\hline \multirow[t]{3}{*}{$\begin{array}{l}\text { GAMMON } \\
\text { INDIA }\end{array}$} & $\begin{array}{l}\text { Pearson } \\
\text { Correlation }\end{array}$ & $.809^{* *}$ & 1 \\
\hline & Sig. (2-tailed) & .000 & \\
\hline & $\mathrm{N}$ & 145 & 145 \\
\hline
\end{tabular}




\section{CORRELATION FOR PUNJ LLOYD}

LIMITED

\begin{tabular}{|c|c|c|c|}
\hline & & NIFTY & PUNJLLOYD \\
\hline \multirow[t]{3}{*}{ NIFTY } & $\begin{array}{l}\text { Pearson } \\
\text { Correlation }\end{array}$ & 1 & $.870^{* * *}$ \\
\hline & $\begin{array}{l}\text { Sig. }(2- \\
\text { tailed })\end{array}$ & & .000 \\
\hline & $\mathrm{N}$ & 145 & 145 \\
\hline \multirow[t]{3}{*}{ PUNJLLOYD } & $\begin{array}{l}\text { Pearson } \\
\text { Correlation }\end{array}$ & $.870^{* *}$ & 1 \\
\hline & $\begin{array}{l}\text { Sig. }(2- \\
\text { tailed })\end{array}$ & .000 & \\
\hline & $\mathrm{N}$ & 145 & 145 \\
\hline \multicolumn{4}{|c|}{$\begin{array}{l}* * \text {. Correlation is significant at the } 0.01 \text { level } \\
\text { (2-tailed). }\end{array}$} \\
\hline
\end{tabular}

\section{CORRELATION FOR HCC LIMITED}

\begin{tabular}{|l|l|c|c|}
\hline \multirow{3}{*}{ NIFTY } & Pearson Correlation & 1 & $.802^{* *}$ \\
\cline { 2 - 4 } & Sig. (2-tailed) & & .000 \\
\cline { 2 - 4 } & $\mathrm{N}$ & 145 & 145 \\
\hline HCC & Pearson Correlation & $.802^{* *}$ & 1 \\
\cline { 2 - 4 } & Sig. (2-tailed) & .000 & \\
\cline { 2 - 4 } & $\mathrm{N}$ & 145 & 145 \\
\hline \multirow{3}{*}{$* *$. Correlation is significant at the 0.01 level } \\
(2-tailed). \\
\hline
\end{tabular}

\section{FINDINGS}

\section{JAIPRAKASH ASSOCIATES LTD}

ROC analysis of JAIPRAKASH ASSOCIATES LIMITED shows that the investor can sell the shares on $8^{\text {th }}$ September 2011 where the percentage of change is 129.7 and the investor can buy the shares on $21^{\text {st }}$ November 2011 where the percentage of change is 77.39 .

$>$ The investor can hold the shares of JAIPRAKASH ASSOCIATES LIMITED for some time as its Relative Strength Index (RSI) is 47.14.
Correlation between JAIPRAKASH ASSOCIATES LIMITED share price and the movement of NIFTY shows 54 percent

DLF LIMITED (.540) positive correlation.

$>$ DLF LIMITED shows $118.8 \%$ of rate of change on $13^{\text {th }}$ October 2011, the investor can sell the shares and $82.19 \%$ of rate of change on $17^{\text {th }}$ November 2011, the investor can buy the shares.

$>$ The Relative Strength Index (RSI) of DLF LIMITED is 49.43 , the investor can hold the shares for some time.

$>$ Correlation between DLF LIMITED share price and the movement of NIFTY shows 47 percent (.473) positive correlation.

\section{GAMMON INDIA LIMITED}

ROC analysis of GAMMON INDIA LIMITED shows that the investor can sell the shares on $27^{\text {th }}$ January 2012 where the rate of change is 120.74 and the investor can buy the shares on $21^{\text {st }}$ November 2011 where the rate of change is 81.372.

The Relative Strength Index (RSI) of GAMMON INDIA LIMITED is 45.56, the investor can hold the shares for some time .

$>$ Correlation between GAMMON INDIA LIMITED share price and the movement of NIFTY shows 80 percent (.809) positive correlation.

PUNJ LLOYD LIMITED

ROC analysis of PUNJ LLOYD LIMITED shows that the investor can sell the shares on $8^{\text {th }}$ September 2011 where the percentage of change is 121.731 and the investor can buy the shares on $16^{\text {th }}$ December 2011 where the rate of change is 78.70 .

$>\quad$ The investor can hold the shares of PUNJ LLOYD LIMITED for some time as its Relative Strength Index (RSI) is 45.11.

$>$ Correlation between PUNJ LLOYD LIMITED share price and the movement of NIFTY shows 87 percent (.870) positive correlation. 


\section{HINDUSTAN CONSTRUCTION COMPANY LTD \\ HINDUSTAN CONSTRUCTION \\ COMPANY shows $124.29 \%$ of rate of change, the investor can sell the shares on $17^{\text {th }}$ January 2012 and $74.68 \%$ of rate of change the investor can buy the shares on $21^{\text {st }}$ November 2011. \\ HINDUSTAN CONSTRUCTION COMPANY have the Relative Strength Index (RSI) of 48.35, the investor can hold the shares for some time. \\ $>$ Correlation between HINDUSTAN CONSTRUCTION COMPANY share price and the movement of NIFTY shows 80 percent (.802) positive correlation.}

\section{SUGGESTIONS}

$>$ Investor must gain basic knowledge about the share market before investing in the shares to get high returns.

$>$ Technical analysis helps to find stock market movements, using this share holder may avoid loss.

> The Relative Strength Index (RSI) of the five construction companies lies between 30 and 70 , it is suggested that the investors can hold the shares for some period.

$>$ The relationships between the Nifty value and the share price of five construction companies have positive correlation. Investor will invest in these to earn more profit.

$>$ The present study suggested that the investors can hold the shares for some period.

\section{CONCLUSION}

In India most of the industries require huge amount of investments. Funds are raised mostly through the issue of share. An investor is satisfied from the reasonable return from investment in shares. Besides the investors are motivated to buy the shares from the stock market either for speculation or investments. Speculation involves higher risks to get return, on the other hand investment involves no such risks and returns will be fair.

An investor can succeed in his investment only when he is able to select the right shares. The investors should keenly watch the situations like market price, economy, company progress, returns, and the risk involved in a share before taking decision on a particular share. This study made will help the investors know the behavior of share prices of five companies in construction sector and thus can succeed. However, the imperfection, inefficiencies, and irrationalities that characterized the real world markets, technical analysis can be helpful.

\section{REFERENCES}

[1] Avadhani "Investment Management", Himalaya Publishing House, New Delhi, $2^{\text {nd }}$ Edition, 1999.

[2] Bhalla V.K., "Investment Management", Security Analysis and Portfolio Managezment, S.Chand \& Co Ltd, New Delhi, $2^{\text {nd }}$ Edition, 1997.

[3] Gupta.S.P. "Statistical Methods", Sultan Chand \& Co, $2^{\text {nd }}$ Edition, 1998.

[4] Kothari.C.R. "Research Methods and Techniques", Wishwa Prakashan Publishing, New Delhi, 1990...

[5] Prasanna Chandra, "Financial Management-Theory and Practice", Tata Mc Graw Hill, International Edition, $5^{\text {th }}$ edition, 2000.

[6] Gupta, L.G (2003). "Stock Market Investors' Biggest Worries Today." Portfolio Organiser. Vol.41, No.5, 2003,p 47-51.

[7] Osler, C.L. (2000).’'Support for Resistance: Technical Analysis and Intraday Exchange Rates," Federal Reserve Bank of New York Econmic Policy Review 6, p 53-65. 